\title{
The Hydrogeochemical Occurrence of Fluoride in Groundwater and Its Effect on Human Health: A Case Study from Sanliurfa, Turkey
}

\author{
Ayse Dilek Atasoy", Mehmet Irfan Yesilnacar \\ Department of Environmental Engineering, Engineering Faculty, Harran University, Osmanbey Campus, Turkey
}

Copyright $(2017$ by authors, all rights reserved. Authors agree that this article remains permanently open access under the terms of the Creative Commons Attribution License 4.0 International License

\begin{abstract}
Fluoride ions in drinking water higher than the permissible level lead to negative effects on the human health. More than 200 million people in the world were adversely affected from the high fluorine water. Endemic fluorosis originating from the consumption of high fluorine water was observed also in some parts of Anatolia, Turkey. Volcanic formations are found in areas with high fluoride concentrations in ground waters. In this study, fluoride concentration in ground water was researched in two villages in Sanliurfa where comprised generally sedimental formations thereupon the identified fluorosis cases on the primary school students.
\end{abstract}

Keywords Fluoride, Hydrogeochemistry, Dental Fluorosis, Sanliurfa

\section{Introduction}

Fluoride is an essential nutrient for the human body at low concentrations [1]. Widespread occurrence of fluoride above the prescribed limit in groundwater meant for human consumption has caused multidimensional health problems, most common being dental fluorosis and skeletal fluorosis. The concentration of fluoride in drinking water ranges between 1 and $25 \mathrm{mg} / \mathrm{L}$. Wide ranges depend on the factors such as the geological, physical and chemical properties of the region and $\mathrm{pH}$, temperature and content of the soil [2]. The current US EPA maximum contaminant level (MCL) of drinking water for fluoride is $4 \mathrm{mg} / \mathrm{L}$ [3]. Preventive effects of optimal dose fluoride have been proven on the dental caries in children and adults. Fluoride in drinking water at low $(<0.5 \mathrm{mg} / \mathrm{L})$ and high concentrations $(>1.5 \mathrm{mg} / \mathrm{L})$ can cause dental caries and teeth spots-dental fluorosis disease, respectively [4-5]. Especially the incidence of fluorosis is higher in human living in rural areas and providing the drinking water from ground waters. Some indices have been developed for the classification of dental fluorosis. Most commonly used of these indexes is Dean Community fluorosis index (Table 1).

Endemic fluorosis occurred in about 30 developed and developing countries -including Turkey in the World. Over 200 million people are damaged because of excessive fluoride in drinking water. Especially high fluoride water have been identified in the north of China, India, Sri Lanka, Mexico, west of the United States, Argentina, and many parts of Africa [6-7]. The high fluoride in drinking water and dental fluorosis was first observed about 55 years ago in Isparta Province, located in the SW of Turkey [8]. High fluorine waters in Turkey were realized also in various areas [9-12]. Fluoride concentrations of waters in these parts of Anatolia ranged between 1.5 and $13.7 \mathrm{mg} / \mathrm{L}$ because of the indicated volcanic rocks and geothermal resources. In this study fluoride research was conducted in Karataş and Sarım villages located in the north-west of Sanliurfa, Turkey. Aim of this research is to investigate the fluoride concentrations of waters in Karataş, Sarım and surrounding villages where the fluorosis cases were identified on the primary school students.

Table 1. Dean's Index

\begin{tabular}{|c|c|}
\hline Normal & $\begin{array}{c}\text { Smooth, glossy, pale creamy-white translucent } \\
\text { surface }\end{array}$ \\
\hline Questionable & A few white flecks or white spots \\
\hline Very Mild & $\begin{array}{c}\text { Small opaque, paper white areas covering less } \\
\text { than 25\% of the tooth surface }\end{array}$ \\
\hline Mild & $\begin{array}{c}\text { Opaque white areas covering less than } 50 \% \text { of the } \\
\text { tooth surface }\end{array}$ \\
\hline Moderate & $\begin{array}{c}\text { All tooth surfaces affected; marked wear on biting } \\
\text { surfaces; brown stain may be present }\end{array}$ \\
\hline Severe & $\begin{array}{c}\text { All tooth surfaces affected; discrete or confluent } \\
\text { pitting; brown stain present }\end{array}$ \\
\hline
\end{tabular}

\section{Materials and Methods}

Dental screening for the fluorosis cases were carried out 
by the dentist from Sanliurfa Provincial Health Directorate on the primary school students in Karataş and Sarım villages located in the North-west of Sanliurfa, Turkey (Figure. 1). These two villages where the first fluorosis cases identified were the first stage of the field study area on the fluoride research. Villagers supplied their drinking and using water from the 100-150 meters deep wells opened in the last 10-15 years. Ground water samples from four different points in the first stage study area were analysed for the essential chemical parameters (Table 2). Because of the high fluoride levels in ground water samples, the study area was expanded through the second stage of the field study to evaluate all the aspects of the problem. Surrounding villages such as Geçitköy, Hurmalı, Cevreli and Yukariaybasti were included in the study area. Major ions and heavy metals analyzes were conducted in ground water samples from 13 wells in these villages (Table 3). Fluoride analysis were achieved by Hach mark (product code: 2589 99) Fluoride Portable Meter by TISAB method. All other parameters were analysed by Standart Methods in the Harran University Central Laboratory.

\section{Results and Discussion}

Low and moderate fluorosis cases were identified on the primary school students in Sarım and Karataş villages (Figure.2). A dentist from Sanliurfa Provincial Health Directorate was appointed to the teeth screening study. High fluoride concentrations were determined in the water samples for the first stage field study (Table 2) and the second stage field study (Table 3 ). Fluoride concentration of water ranged between 1 and $4 \mathrm{mg} / \mathrm{L}$. These values are over the limits for national legal regulations and permissible limits $(0.5-1.5 \mathrm{mg} / \mathrm{L})$ that were recommended by the WHO [13]. However, high fluorine waters were not detected in any well in neighboring villages (Çevreli, Hurmalı, Geçitköy, Y.Aybastı) (Table 3).

High concentration of fluoride in groundwater is related to the geological conditions. Mostly these areas are either near the fluorite reserves or contain the volcanic soil structures. Natural fluorosis diseases or other health effects occurred especially on the volcanic areas. The geological structure of Sanliurfa shows widely volcanic and sedimentary rocks as two main formations. Supplied drinking water of villagers was from the basalts around the Karacadag volcanic formation (about $132 \mathrm{~km}$ to study area). However no any dental fluorosis cases occurred in this area. Source of high fluoride in water is thought to be originated from the phosphate deposits in Mazı Mountain in Mardin close to the study area. However, high-fluoride problem in this region was not reported in "Turkey's Water Fluoride Map" $[14,15]$. The researches in the past were shown that fluoride concentrations in waters were between 0.06 and $0.13 \mathrm{mg} / \mathrm{L}$ in Sanliurfa [16]. Despite the permissible F levels in water resources in neighboring regions, to identify high fluorine water in ground water in Sarım and Karataş villages in Sanliurfa was an interesting result.

Table 2. Analysis results in the villages of Sarım and Karataş (first stage field study)

\begin{tabular}{ccccc}
\hline Analysis & Karataş 1 & Karataş 2 & Karataş 3 & Sarım \\
\hline Turbidity (NTU) & 0,50 & 0,90 & 0,50 & 1,10 \\
$\mathbf{p H}$ & 8,15 & 8,25 & 8,24 & 8,43 \\
$\begin{array}{c}\text { Electrical } \\
\text { Conductivity-EC } \\
(\boldsymbol{\mu S} / \mathbf{c m})\end{array}$ & 275 & 300 & 224 & 275 \\
$\begin{array}{c}\left.\text { Temperature ( }{ }^{\circ} \mathbf{C}\right) \\
\text { Fluoride }(\mathrm{mg} / \mathrm{L})\end{array}$ & 17,60 & 17,10 & 18,20 & 17,30 \\
Nitrate (mg/L) & $\mathbf{2 , 8 4}$ & $\mathbf{2 , 0 1}$ & $\mathbf{1 , 3 2}$ & $\mathbf{3 , 4 8}$ \\
\hline
\end{tabular}



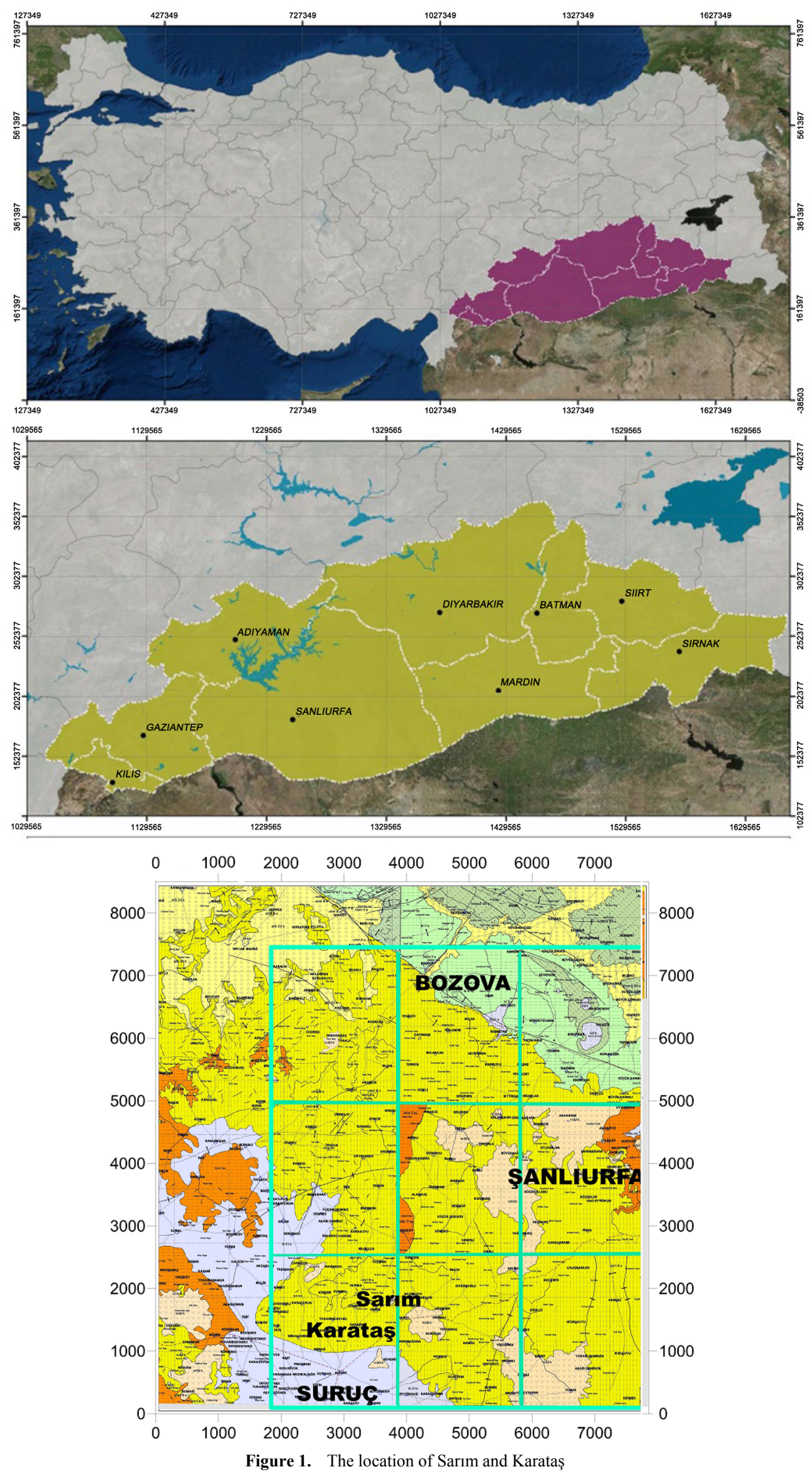

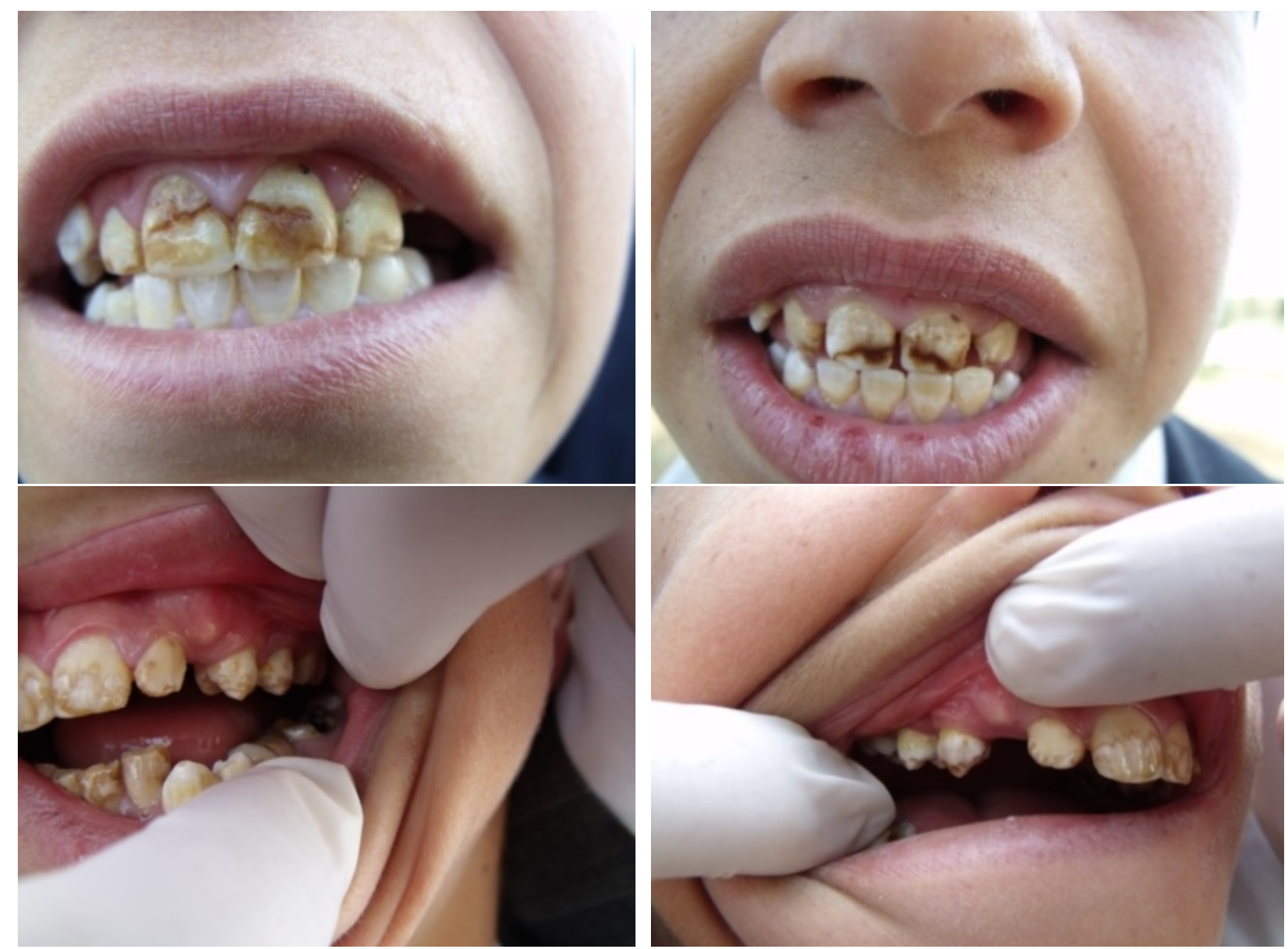

Figure 2. The case of dental fluorosis in primary school students in Sarım and Karataş 
Table 3. Chemical analysis results of water samples from the villages (second stage field study)

\begin{tabular}{|c|c|c|c|c|c|c|c|c|c|c|c|c|c|}
\hline Parameters & Karataş1 & Karataş2 & Karataş3 & Karataş4 & Karataş5 & Sarım 1 & Sarım2 & Çevreli1 & Çevreli2 & Çevreli3 & Hurmalı & Geçitköy & Y.Aybast \\
\hline $\mathrm{Ca}(\mathrm{mg} / \mathrm{L})$ & 39 & 49 & 57 & 56 & 71 & 37 & 57 & 55 & 56 & 128 & 51 & 88 & 22 \\
\hline $\operatorname{Mg} \quad(\mathrm{mg} / \mathrm{L})$ & 24 & 24 & 7 & 10 & 9 & 22 & 10 & 17 & 10 & 25 & 11 & 8 & 17 \\
\hline $\mathrm{Na}(\mathrm{mg} / \mathrm{L})$ & 19 & 18 & 9 & 11 & 5 & 35 & 7 & 10 & 5 & 19 & 5 & 5 & 107 \\
\hline $\mathrm{K}(\mathrm{mg} / \mathrm{L})$ & 3 & 3 & 2 & 1 & 1 & 3 & 1 & 3 & 1 & 5 & 1 & 5 & 6 \\
\hline $\mathrm{HCO}_{3}(\mathrm{mg} / \mathrm{L})$ & 205 & 185 & 145 & 150 & 200 & 200 & 145 & 175 & 145 & 160 & 160 & 195 & 250 \\
\hline $\mathrm{SO}_{4}(\mathrm{mg} / \mathrm{L})$ & 19 & 21 & 9 & 7 & 5 & 25 & 8 & 4 & 6 & 23 & 11 & 7 & 64 \\
\hline $\mathrm{Cl}(\mathrm{mg} / \mathrm{L})$ & 10 & 16 & 11 & 9 & 6 & 14 & 7 & 3 & 7 & 48 & 10 & 9 & 37 \\
\hline F (mg/L) & 4 & 2 & 1 & 0.8 & 0.3 & 4 & 1 & $\mathbf{0}$ & $\mathbf{0}$ & $\mathbf{0}$ & $\mathbf{0}$ & $\mathbf{0}$ & $\mathbf{0}$ \\
\hline $\mathrm{NO}_{3}(\mathrm{mg} / \mathrm{L})$ & 6 & 19 & 32 & 18 & 21 & 7 & 17 & 6 & 24 & 226 & 23 & 41 & 3 \\
\hline $\mathrm{PO}_{4}(\mathrm{mg} / \mathrm{L})$ & 59 & 61 & 18 & 16 & 19 & 71 & 19 & 8 & 20 & 217 & 34 & 66 & 194 \\
\hline $\mathrm{pH}$ & 7.6 & 8 & 7.5 & 7.5 & 7.9 & 7.6 & 7.9 & 8 & 7.9 & 7.6 & 7.8 & 7.6 & 7.5 \\
\hline $\begin{array}{c}\text { Conduct } \\
\left(\mu \mathrm{mho} \mathrm{cm}^{-1}\right)\end{array}$ & 457 & 410 & 358 & 328 & 329 & 446 & 342 & 412 & 322 & 913 & 367 & 471 & 704 \\
\hline $\mathrm{TDS}(\mathrm{mg} / \mathrm{L})$ & 297 & 267 & 232 & 213 & 214 & 290 & 222 & 268 & 209 & 593 & 238 & 306 & 458 \\
\hline Temp. $\left({ }^{\circ} \mathrm{C}\right)$ & 21.6 & 20 & 22 & 23 & 24 & 21 & 22 & 25 & 22 & 21 & 19 & 20 & 19 \\
\hline Depth (m) & 110 & 140 & 110 & 100 & 95 & 220 & 110 & 140 & 90 & 100 & 180 & 180 & 150 \\
\hline
\end{tabular}




\section{Conclusions}

1. Water supply from the former wells that were opened by villagers on their own efforts must be inhibited. New proper water resources must be researched as soon as possible.

2. If the resources are limited, defluoridation applications should be processed on the current high fluorine waters.

3. Dental screening activities on the primary school students should be advanced and this activity must be ensured continuity in the region.

4. The origin of the high fluoride levels in water should be investigated with the examining of hydrogeochemical structure of the region.

\section{Acknowledgements}

This study was funded by the Scientific \& Technological Research Council of Turkey (TUBITAK project no: 110Y234) and the Scientific Research Projects Committee of Harran University, (HÜBAK) under grant no. 2011-1167. The authors would like to thank to Dr. Murat Şahin (dentist from Sanliurfa Provincial Health Directorate) for his careful and selfless supports in the field.

\section{REFERENCES}

[1] Tang, Y., Guan, X., Wang, J., Gao, N., McPhail, M.R., Chusuei, C.C., (2009) Fluoride adsorption onto granular ferric hydroxide: Effects of ionic strength, $\mathrm{pH}$, surface loading, and major co-existing anions. J Hazard Mater 171, 774-779.

[2] Dissanayake, C.B., Chandrajith, R., (2009) Introduction to Medical Geology. Erlangen Earth Conference Series, Springer-Verlag Berlin Heidelberg.

[3] Sun, Y., Fang, Q., Dong, J., Cheng, X., Xu, J., (2011) Removal of fluoride from drinking water by natural stilbite zeolite modified with Fe (III). Desalination 277, 1:3, 121-127.

[4] Yadav, J.P., Lata, S., Kataria, S.K., Kumar, S., (2009) Fluoride Distribution in Groundwater and Survey of Dental Fluorosis
Among School Children in The Villages of The Jhajjar District of Haryana, India. Environ Geochem Health 31, 431438.

[5] Hussain, J., Hussain, I., Sharma, K.C., (2010) Fluoride and Health Hazard: Community Perception in Fluoric area of central Rajasthaqn (India) an Arid Environment. Environ Monit Assess 162, 1-14.

[6] Fuge, R., Andrews, M.J., (1988) Fluorine in the UK Environment. Environ. Geochem. Health 10, 96-104.

[7] Edmunds, M., Smedlley, P., (2005) Fluoride in Natural Waters. Essentials of Medical Geology 12, 301-315.

[8] Örnek, S., (1955) Diş çürüklerinde ve diş Florozisinde Memleket Sularının Ihtiva Ettikleri Florun Rolü. Ankara Üni. Tip Fak. Mecmuası 1955 V: 7-8, 4, 129-137.

[9] Oruç, N.A., (1977) Preliminary Study on The Effect of Water-borne Fluoride on The Fluoride Content of Soils and Plants. CENTO Scientific Problems, Erzurum Atatürk Unv. Report No: 28.

[10] Oruç, N., (2001) Türkiye'de Yüksek Düzeyde Florür İçeren Kaynak Suları ve Önemi. 1. Türkiye Su Kongresi, 8-10 Ocak 2001, İstanbul, İTÜ ve İstanbul Büyükşehir Belediyesi Organizasyonu, 629-638.

[11] Oruç, N., (2008) Occurrence and problems of high fluoride waters in Turkey: an overview. Environmental Geochemistry and Health 30, 315-323.

[12] Sendil, C., Baysu, N., (1973) İnsan ve Hayvanlarda Ağrı İli Muradiye İlçesi Köylerinde Saptamamızla İlgili İlk: Tebliğ. Ankara Uni. Veteriner Fak. Dergisi. Cilt:20, No:4

[13] WHO, (1994), Technical report series, Fluorides and oral health, report of a WHO Expert Committee on Oral Health Status and Fluoride Use. WHO, Geneva, p 17.

[14] Anonymous (2003) Türkiye'nin Su Fluor Haritası. Sağlık Bakanlığı, Ana Çocuk Sağlığı ve Aile Planlaması Genel Müdürlüğü, 442.

[15] Anonymous (2010) Mardin İli Maden ve Enerji Kaynakları, 2010 MTA,

http://www.mta.gov.tr/v1.0/turkiye_maden/maden_potansiye 1_2010/Mardin_Madenler.pdf (Date: 25.08.2010)

[16] Kösecik, M., Ataş, A., Emiroğlu, H.H., Tatlı, M.M., Fidanc1, U.R., Aktepe, N., (1999) Sanliurfa içme sularında flor düzeyleri. Klinik Bilimler ve Doktor 5, 517-519. 